\title{
Population dynamics of subtidal blue mussels Mytilus edulis and the impact of cultivation
}

\author{
Jacob J. Capelle ${ }^{1,2, *}$, Marnix R. van Stralen ${ }^{3}$, Jeroen W. M. Wijsman' ${ }^{\text {, }}$ \\ Peter M. J. Herman ${ }^{4}$, Aad C. Smaal ${ }^{1,2}$ \\ ${ }^{1}$ Department of Aquaculture and Fisheries, Wageningen University, PO Box 338, $6700 \mathrm{AH}$, Wageningen, The Netherlands \\ ${ }^{2}$ Wageningen University \& Research - Wageningen Marine Research, PO Box 77, 4400 AB, Yerseke, The Netherlands \\ ${ }^{3}$ MarinX Consultancy, Elkerzeeseweg 77, 4322 NA, Scharendijke, The Netherlands \\ ${ }^{4}$ Deltares, PO Box 177, $2600 \mathrm{MH}$, Delft, The Netherlands
}

\begin{abstract}
Fishery on subtidal mussel beds and subsequent relying on culture plots in the same system is a common practice in bottom mussel culture. We address factors that determine the population dynamics of subtidal blue mussels Mytilus edulis L. and to what extent total (natural plus cultured) subtidal mussel biomass in the system is affected by fishery practices. Mussel size and density of spatially segregated natural and cultured subtidal mussel populations in the western Wadden Sea were measured over time in 2 field studies. Spatial patterns in survival rates showed better spat survival in areas with lower salinity and lower density of sea stars Asterias rubens. This suggests that mussel survival is negatively related to sea star distribution which is to a large extent controlled by salinity. The Asterias-Mytilus relation in the Wadden Sea is an example of the concept that environmental stress determines the successes of the prey by affecting the preypredator relationship. Natural beds that escape predation are found at lower salinities, and mussels on these beds showed low growth rates, also because of lower food quality in these areas. Mussel culture is strongly affecting the population dynamics of the subtidal mussel population, through relay of mussels from natural mussel beds to culture plots. This activity increases mussel growth and survival, because food quality on culture plots is high and predation is controlled. Despite harvesting, mussel biomass production on culture plots was higher than on natural mussel beds, enhancing total subtidal mussel stock.
\end{abstract}

KEY WORDS: Ecosystem goods and services $\cdot$ Salinity $\cdot$ Asterias rubens $\cdot$ Sea star $\cdot$ Aquaculture impact $\cdot$ Sampling $\cdot$ Bottom culture $\cdot$ Wadden Sea

\section{INTRODUCTION}

Bottom culture of mussels is an extensive largescale form of aquaculture that is practiced in shallow subtidal and intertidal sand/mud flats in coastal areas (Gosling 2003). The overall impact of this type of culture is in general low compared to other more intensive forms of aquaculture (Davenport et al. 2009). However, the shallow sand/mudflats are habitats for ecologically important habitat-creating communities (e.g. mussels, sea grasses, oysters, Sabellaria) and vital foraging areas for birds and fishes

${ }^{*}$ Corresponding author: jacob.capelle@wur.nl
(Lenihan \& Micheli 2001, Van de Kam et al. 2004). These ecological values may be impacted by culture activities, which include the translocation of juvenile mussels from natural beds (mussel seed) to culture plots.

Major concerns about the environmental impacts of mussel culture include the effects on predatory birds in subtidal areas, especially eider ducks, and to a lesser extent greater scaup (Smit et al. 1998, Piersma \& Camphuysen 2001, Stillman et al. 2001, Laursen et al. 2009). Effects of mussel seed fishery on benthic biodiversity, habitat structure and natural

(C) The authors 2017. Open Access under Creative Commons by Attribution Licence. Use, distribution and reproduction are unrestricted. Authors and original publication must be credited. 
mussel stocks are also debated (Dolmer et al. 1999, 2012, Herlyn \& Millat 2000, Smith \& Shackley 2004, Murray et al. 2007a). Mussel beds are considered among the most diverse temperate communities (Suchanek 1992). Effects of mussel dredging on soft sediment include the removal of larger substrates such as shell debris and gravel (Frandsen et al. 2015). Experiments in the Limfjord showed that abundance of several taxa (sponges, echinoderms, anthozoans, molluscs, crustaceans, ascidians) were still reduced 4 mo after dredging (Dolmer et al. 2001). Most of these species are associated with hard substrate, such as mussel shells, provided by the mussel bed. Apart from removing mussels with associated flora and fauna, impacts of dredging on biodiversity may be habitat specific, as such effects are less pronounced in more exposed and sandy environments (Kaiser et al. 2006).

Mussels are ecosystem engineers that provide important ecosystem functions, such as benthic-pelagic coupling, food and habitat for other species (Borthagaray \& Carranza 2007, Gutiérrez et al. 2011). Most studies on mussel populations have been carried out on intertidal mussel beds, probably because they are more abundant and more accessible than subtidal mussel beds. Intertidal beds can persist on the same spots for decades, re-establishing periodically with new spatfall (McGrorty et al. 1990, Brinkman et al. 2002, Büttger et al. 2008, Commito et al. 2014, Folmer et al. 2014). In contrast, subtidal beds and to some extent intertidal beds at exposed locations are often described as ephemeral as a result of sea star predation or dislodgement during storms (Nehls \& Thiel 1993, Reusch \& Chapman 1997, Beadman et al. 2003, Agüera 2015). Indeed, there are concerns on the impact of mussel culture on subtidal seed beds, specifically to what extent fishery prevents the development of viable subtidal mussel beds (Dankers \& Zuidema 1995, Kaiser et al. 1998, Asmus \& Asmus 2002, Lotze et al. 2005). Yet, factors determining the resilience of subtidal mussel beds are often unknown, and the effects of extensive aquaculture on the population dynamics of subtidal mussels are not clear (Commito \& Dankers 2001, Nehls et al. 2009).

In this study, we address which factors determine the population dynamics of subtidal blue mussel Mytilus edulis (hereafter simply 'mussels') and to what extent the total (natural plus cultured) subtidal mussel biomass in the system is affected by fishery practices, such as mussel seed dredging, relaying and subsequent harvesting. We compare mussel biomass development on both natural beds and culture plots within the western Wadden Sea, the largest mussel bottom culture area in Western Europe. Culture takes place on 7700 ha of leased culture plots, of which 4000 ha are effectively used by about 60 mussel-producing companies. The Wadden Sea is also a globally important area for nature conservation. Mussel seed in the Wadden Sea is traditionally dredged from subtidal natural beds and translocated to culture plots within the same system. A substantial amount of mussel seed is also obtained from floating seed mussel collectors (SMCs).

Here, we tested whether mussel culture is an important factor in determining the population dynamics of the subtidal mussel population, because, due to management measures by the farmers, cultured mussels display higher growth and survival rates than mussels on natural subtidal beds that are subject to predation, physical factors such as waves and currents, and low site-specific recruitment. Mussel cohort dynamics on natural mussel beds and on culture plots were monitored over time. To test differences in growth and survival, mussel cohorts on natural mussel beds and culture plots were monitored for 6 and $4 \mathrm{yr}$, respectively; results were then integrated in a biomass production model, to compare mussel biomass development between natural and cultured mussel populations.

\section{MATERIALS AND METHODS}

\section{Study area}

The Wadden Sea is a shallow intertidal area of about $6000 \mathrm{~km}^{2}$, stretching over 3 countries, viz. The Netherlands, Germany and Denmark. It is separated from the North Sea by a range of barrier islands and from the mainland by dikes. The western part of the Wadden Sea (Fig. 1) is a very dynamic area, which receives a yearly average freshwater input of ca. $450 \mathrm{~m}^{3} \mathrm{~s}^{-1}$ from Lake IJssel (Duran-Matute et al. 2014) and connects to the North Sea through 3 major inlets (Marsdiep, Eierlandse gat and Vliestroom) in the north. The water volume exchange between the different tidal basins of the Wadden Sea is limited compared to the volume exchanged with the North Sea (Ridderinkhof et al. 1990). All mussel culture plots in the Dutch Wadden Sea are found in the western part (Fig. 1a). Fig. 1b (Alterra 2005) displays the areas in the same system where subtidal natural mussel beds were regularly observed from 1992 to 2005. Fishery on natural mussel beds is carried out in autumn and spring, and collects small ('seed') mussels to be relayed on the culture plots. 

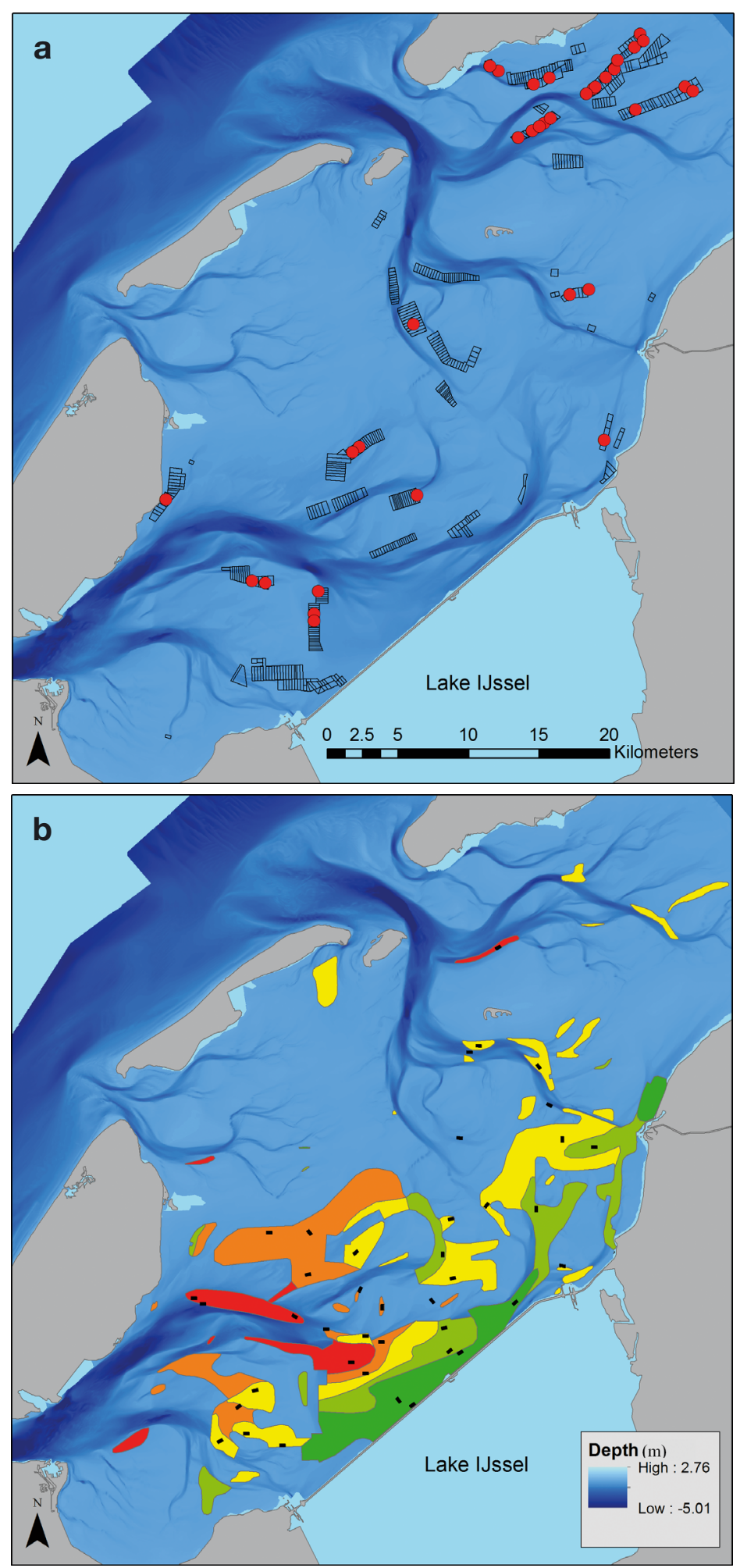

Fig. 1. Areas in the Wadden Sea (Netherlands) (a) with mussel Mytilus edulis culture plots (black polygons); red dots show sampling locations used in the analysis; and (b) where natural subtidal mussel beds are regularly formed, including 5 classes of relative stability (Alterra 2005), where red indicates relative stability and green indicates relative instability; black dots are experimental 8 ha plots. Depth is relative to mean water level
Culture plots are located in areas where natural seedbed formation seldom occurs, since farmers like to avoid spatfall on culture plots, because it causes an undesirable mixing of different size classes. As a result, culture plots are spatially separated from areas where the majority of natural mussel beds are found (Fig. 1). Natural mussel populations are found in areas with lower salinities (close to the Lake IJssel-Marsdiep area), whereas the majority of the culture plots are located in areas with higher salinities (close to the North Sea-Vlie area) (Drent \& Dekker 2013). Suspended particulate matter (SPM) is also higher in the Marsdiep area compared with the Vlie area (on average respectively about 50 and $30 \mathrm{~g} \mathrm{~m}^{-3}$, respectively; see Fig. 9 in De Jonge et al. 1996), because of discharges from Lake IJssel (De Jonge \& De Jong 2002).

\section{Sampling of natural subtidal mussel beds}

Growth and specific loss rates of mussel populations on natural subtidal beds were determined from a sampling program designed to investigate the effects of mussel seed fishery on biodiversity and natural mussel stock (Van Stralen et al. 2013).

Natural mussel seed beds originate from natural spatfall and appear during summer. In autumn of every year from 2006 to 2009, all newly formed mussel seed beds were studied by the creation of experimental plots of 8 ha in the newly established mussel seed bed (Fig. 1b). The experimental plots were split in 2 (split-plot design), with one half (4 ha) closed and the other half open for mussel seed fishery. Within the 2 subplots $(200 \times 200 \mathrm{~m}$, i.e. 4 ha each) inside the experimental plot, a buffer zone of $50 \mathrm{~m}$ was created at the edges, leaving an area of $100 \times 100 \mathrm{~m}$ in the centre of the subplots. In total, 40 experimental plots were created this way. Sampling was carried out in the period 2006 to 2012 and continued beyond 2012 until the natural beds formed between 2006 and 2012 were all gone. In the present study, we only used data collected between 2006 and 2012. This set-up provided largescale quantitative information on mussel growth and specific loss rates on plots closed for fishery, which can be seen as representa- 
tive for all major natural seed beds formed in the western Wadden Sea between 2006 and 2012.

Sampling of experimental plots was done with a suction dredge or, when water depth exceeded $8 \mathrm{~m}$, with a trawled dredge. Two transects of about $100 \times$ $0.2 \mathrm{~m}$ (suction dredge) or about $100 \times 0.1 \mathrm{~m}$ (trawled dredge) each were sampled per experimental subplot open for fishery, and similarly, 2 similar sized transects were sampled per closed subplot. Actual sampling track lengths were measured with a handheld GPS for the suction dredge, while a rotating wheel with a magnetic counter was used for the trawled dredge. Experimental plots within new seed beds or on which a new seed bed was re-established during the course of the experiment were always sampled before and after fishery in autumn and spring. Experimental plots with mussels aged $>1 \mathrm{yr}$ were always sampled in spring. In the majority of cases, only 1 year-class remained per experimental plot. However, when new spatfall occurred on an existing plot, separate year-classes were considered in the analysis. An extensive schedule of sampling events per location can be found in the study of Van Stralen et al. (2013).

Average mussel density and biomass $\mathrm{m}^{-2}$ were calculated by dividing the total number of mussels and total mussel wet weight by the sampled area. Yearclasses of mussels used in the present study were followed by this method until April 2012.

We assumed that sampled plots are representative of the natural beds on which the plots were created. Hence, fishing activities around the area (4 ha) closed to fishery should not have a measurable effect on the experimental plots. This was tested by Van Stralen et al. (2013) by investigating gradients in mussel density on a $50 \mathrm{~m}$ buffer zone and on a $100 \times$ $100 \mathrm{~m}$ inner plot. In that analysis, it was assumed that if fishing activities had any effect on mussels in experimental plots closed for fishery, it would have created gradients in mussel density from the edge to the middle of the plot. Results of the analysis showed no such patterns and suggest no effect of fishing activities in the area surrounding the plots closed for fishery.

\section{Sampling of subtidal culture plots}

Estimates of mussel growth and mortality rates from culture plots were obtained from a sampling program in which 66 mussel cohorts were followed over time on 42 different culture plots in the western Wadden Sea using a methodology published by Capelle et al. (2016). Mussels on the plots originated from fishery on natural beds $(\mathrm{n}=29)$ and from seed harvested from submerged mussel spat collectors $(n=22)$, or with seed relayed from other culture plots (n = 15).

\section{Data analysis}

Growth

A von Bertalanffy growth function (VBGF), with sinusoidal correction for seasonal temperature fluctuations (Somers 1988), was fitted to the length measurements $(L, \mathrm{~mm})$ from the culture plots and natural seed beds:

$$
\begin{aligned}
& L_{t}=L_{\infty}\left\{1-\mathrm{e}^{-\left[K\left(t-t_{0}\right)+S(t)-S\left(t_{0}\right)\right]}\right\}, \\
& \text { with } S(t)=\frac{C K}{2 \pi} \sin \left[2 \pi\left(t-t_{S}\right) / 365\right]
\end{aligned}
$$

where $K$ is the growth coefficient $\left(\mathrm{d}^{-1}\right), L_{\infty}$ is the asymptotic length $(\mathrm{mm}), L_{t}$ is the length $(\mathrm{mm})$ at age $t(\mathrm{~d}), C$ is a dimensionless constant determining the magnitude of the oscillation, $t_{s}$ defines the beginning of a sine wave (with a wave length of $1 \mathrm{yr}$ ), and $t_{0}$ is the theoretical age where $L_{t}$ is 0 (Somers 1988). Fitting the model to the measured length data with Eq. (1) was achieved by a generalised nonlinear least-squares routine from the nlme library (Pinheiro et al. 2014) for the software R (R Core Team 2016), by which heterogeneous errors were accounted for and assumptions of the full model (fitted on data from natural beds and culture plots together) were met by the data.

Growth between mussels on natural beds and culture plots was compared following the likelihood methodology of Kimura (1980) and its implementation by Ogle (2015a), with the help of the FSA package for R (Ogle 2015b). In this method, a complex model with all parameters of the VBGF different for natural beds and culture plots are compared to simpler nested models, with 1 or more VBGF parameters in common. Models are compared with a likelihood ratio test, and this process stops when a more complex model is significantly different from every simpler nested model. The resulting best model was fitted to the data over a period of $2.5 \mathrm{yr}$, because mussels on culture plots were not followed for longer than $2.5 \mathrm{yr}$.

\section{Mussel loss}

Specific loss rates $\left(r, \mathrm{~d}^{-1}\right)$ of the mussels on the natural mussel beds and culture plots were calculated by the change in mussel density $\left(D\right.$, no. $\left.\mathrm{m}^{-2}\right)$ over 
time $(t, d)$ assuming an exponential population decline. Specific loss rates were calculated as the change in mussel density found between the first sampling $\left(D_{1}\right)$ and subsequent second sampling $\left(D_{2}\right)$, with $t$ as the time interval in days.

$$
r=-\frac{\ln \left(D_{2}\right)-\ln \left(D_{1}\right)}{t}
$$

Densities of mussels older than $2.5 \mathrm{yr}$ were excluded from the analysis, because mussels on culture plots were not followed for longer than 2.5 yr. Measurements were excluded from the analysis if both $D_{1}$ and $D_{2}<10$ ind. $\mathrm{m}^{-2}$ to prevent inflation of $r$. Average mussel length $(\bar{L})$ was calculated for each $r$ as: $\left(L_{2}-L_{1}\right) / 2$, with $L_{1}$ and $L_{2}$ corresponding to $D_{1}$ and $D_{2}$, respectively. Culture plots are located in areas with higher salinity, while natural mussel beds are found in areas where average salinity is lower with more fluctuations (Drent \& Dekker 2013 and see Fig. 7.2 in Agüera et al. 2015). Annual average salinity values for each culture plot and for each experimental plot on the natural beds were calculated (data RIKZ; summarized in Fig. 2). Salinity in the Wadden Sea shows seasonal fluctuations, with the lowest values in winter and the highest in summer; van Aken (2008) reported that maximum and minimum values in the Marsdiep area (western part of the Wadden Sea) differed by ca. 2 ppt.

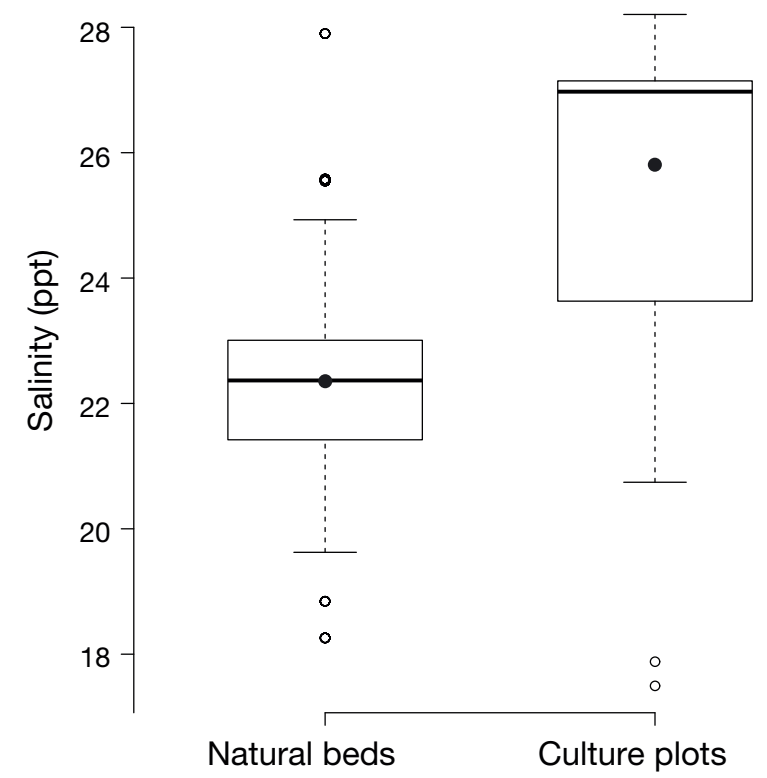

Fig. 2. Averaged yearly salinity values (boxplot with median, first and third quartile, $95 \%$ confidence interval of median and outliers) for natural mussel Mytilus edulis beds and culture plots that were sampled in this study; filled dots represent mean values
Specific loss rates as a function of salinity and $\bar{L}$ were investigated for natural mussel populations and for mussels on culture plots. We used a generalised least-squares model with the varIdent function in $\mathrm{R}$ allowing for different variances for each type (Pinheiro et al. 2014).

Spatial variation in specific loss rates were visualised by plotting $r$ in graduated symbols on a map of the area for culture plots and natural beds, respectively. Spatial variation in salinity is indicated in the same map with contour lines.

\section{Biomass}

Biomass $\left(B, \mathrm{~kg} \mathrm{~m}^{-2}\right)$ on culture plots and natural mussel beds was simulated over time, using the output of Eqs. (1) and (2) as:

$$
B_{t}=W_{t} \times D_{t}
$$

with $W_{t}(\mathrm{~g})$ obtained by converting mussel length as output of Eq. (1) to mussel wet weight according to $W_{t}=1.43 \times 10^{-4} \times L_{t}^{2.89}$ (Capelle et al. 2016). $D_{t}$ was obtained from change in mussel density over time:

$$
D_{t}=D_{0} \times \mathrm{e}^{-r t}
$$

with $r$ as either $r_{\text {culture }}$ or $r_{\text {natural }}$ as a constant, or as function of length and salinity when regression analysis indicated a significant relation. Additionally, the loss is corrected for density-dependent seeding loss estimated by: $D_{t 1}=\mathrm{e}^{\left[0.52 \cdot \ln \left(D_{\text {seed }}\right)+2.62\right]}$ (Capelle et al. 2016), where $D_{t 1}$ is mussel density on the culture plot after seeding, and $D_{\text {seed }}$ is seeding density. Total mussel loss on culture plots is the combination of $r_{\text {culture }}$ and density-dependent loss directly after seeding.

\section{RESULTS}

Data are summarized in Fig. 3, with the biomass distribution $\left(\mathrm{kg} \mathrm{m}^{-2}\right)$ of mussels at the subsequent sampling times on natural mussel beds and on culture plots.

\section{Mussel growth}

The likelihood ratio test between VBGF with separate versus common parameters for mussel growth provides evidence that VBGF parameters differ between mussels on natural beds and mussels on culture plots. The most parsimonious model had sepa- 


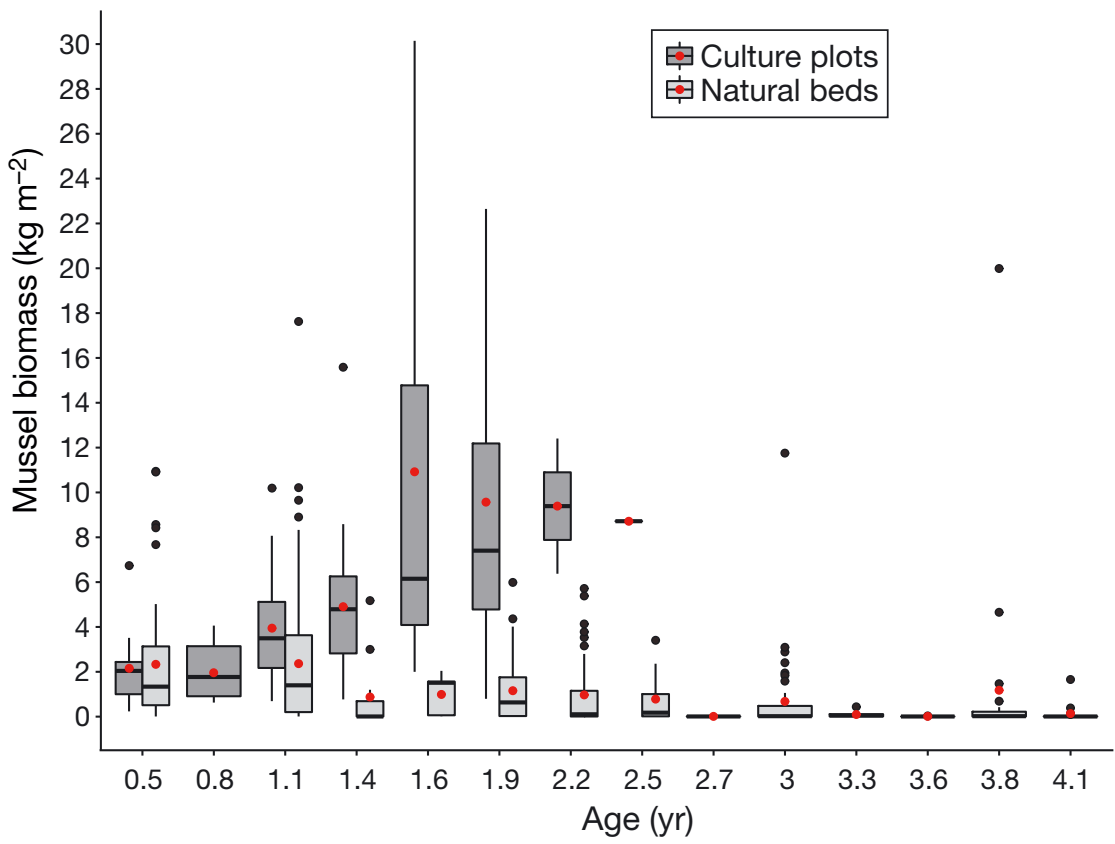

Fig. 3. Accumulated mussel biomass found on culture plots and on natural mussel Mytilus edulis beds in the Wadden Sea for different mussel ages; reference date of age 0 is 17 April. Red dots represent mean values. Other boxplot details as in Fig. 2

rate VBGF parameters $L_{\infty}$ and $C$ between groups (Table 1). The difference between this 'best model' and the model with all VBGF parameters in com$\operatorname{monc}\left(\chi^{2}=108.69, \mathrm{p}<0.001\right)$ confirms that differences between groups exist and that the difference is only evident for the $L_{\infty}$ and $C$ parameters in Eq. (1).

Growth fitted with 2 VBGFs for natural mussel beds and culture plots, with parameter estimates from Table 1, is displayed in Fig. 4. Cultured mussels reached a higher asymptotic length and a faster growth than mussels on natural beds. The length difference between the 2 groups was on the order of 20 to $25 \%$.

Table 1. Estimated parameters of the von Bertalanffy growth function (VBGF) for culture plots and natural mussel Mytilus edulis beds. $L_{\infty}$ : asymptotic length $(\mathrm{mm}), K$ : growth coefficient $\left(\mathrm{d}^{-1}\right), t_{0}$ : theoretical age at which length is $0, C$ : constant determining the magnitude of the oscillation, $t_{\mathrm{s}}$ : beginning of a sine wave

\begin{tabular}{|c|c|c|c|c|}
\hline \multirow{2}{*}{$\begin{array}{l}\text { VBGF } \\
\text { Parameter }\end{array}$} & \multicolumn{2}{|c|}{ Culture plots } & \multicolumn{2}{|c|}{ Natural mussel beds } \\
\hline & Estimate & $\mathrm{SE}$ & Estimate & SE \\
\hline$L_{\infty}$ & 69.86 & 2.28 & 60.20 & 1.59 \\
\hline$K$ & 0.82 & 0.072 & 0.82 & 0.072 \\
\hline$t_{0}$ & 0.13 & 0.029 & 0.13 & 0.029 \\
\hline$C$ & 0.95 & 0.11 & 0.68 & 0.096 \\
\hline$t_{\mathrm{s}}$ & 0.19 & 0.018 & 0.19 & 0.018 \\
\hline
\end{tabular}

\section{Mussel loss rate}

Mean \pm SD specific loss rate for natural beds $\left(r_{\text {natural }}\right)$ was $1.05 \times 10^{-2} \pm 1.40 \times 10^{-2}$. However, for the natural mussel population, loss rate was significantly related to shell length and salinity (Fig. 5), with a negative linear relation between specific loss rate and shell length: $r_{\text {natural }}=-2.65 \pm$ $10^{-4} \times \bar{L}+1.95 \times 10^{-2}$ (with SE slope $=9.05$ $\times 10^{-5}, \mathrm{SE}$ intercept $=3.63 \times 10^{-3}, \mathrm{p}=$ $0.004, R^{2}=0.05$ ) and a positive linear relation with annual averaged salinity according to: $r_{\text {natural }}=\left(2.96 \times 10^{-3}\right) \times$ salinity $-(5.57$ $\times 10^{-2}$ ) (with SE slope $=6.77 \times 10^{-4}$, SE intercept $=1.49 \times 10^{-2}, \mathrm{p}<0.001, \mathrm{R}^{2}=0.11$ ).

No such relation was found for mussels on culture plots. The mean $\pm \mathrm{SD}$ specific loss rate for the culture plots ( $\left.r_{\text {culture }}\right)$ was $2.71 \times 10^{-3} \pm 5.01 \times 10^{-3}$.

The effects of mean shell length $(\bar{L})$ and salinity on specific loss rate for the natural mussel population were further investigated using a combined model, according to: $r_{\text {natural }}=\mathrm{a}+\mathrm{b} \times \bar{L}+\mathrm{c} \times$ salinity $+\mathrm{d} \times \bar{L} \times$ salinity, with estimated coefficients (SE) a $=-0.16\left(4.70 \times 10^{-2}\right), b=2.80 \times 10^{-3}\left(1.18 \times 10^{-3}\right), C=$ $8.23 \times 10^{-3}\left(2.10 \times 10^{-3}\right), d=-1.37 \times 10^{-4}\left(5.26 \times 10^{-5}\right)$. The significance of the model parameters was tested with an analysis of variance (ANOVA), the results of which are summarized in Table 2. Shell length $(\bar{L})$ and salinity were very weakly correlated $(r=-0.05)$.

Specific loss rate from plots on natural mussel beds (Fig. 5) shows a general pattern that is very similar to the map of annual mean salinity (Duran-Matute et al. 2014), while for culture plots, no obvious spatial relation appeared (Fig. 6). Salinity contours on the map confirm that no viable natural mussel populations were found in high-salinity zones, or in the extreme low-salinity zones (<17.5 ppt), while the majority of the cultured population was found within the highersalinity zones (Fig. 2).

Table 2. Statistical result of ANOVA performed to examine relation between specific loss rates on natural mussel Mytilus edulis beds with mean shell length $(\bar{L})$ and salinity $(S)$ and their interaction; ${ }^{*} \mathrm{p}<0.05,{ }^{* *} \mathrm{p}<0.01,{ }^{* * *} \mathrm{p}<0.001$

\begin{tabular}{|lcccc|}
\hline Variable & df & MS & $F$ & $\mathrm{p}$ \\
\hline $\bar{L}$ & 1 & $1.56 \times 10^{-3}$ & 10.09 & $0.002^{* *}$ \\
$S$ & 1 & $3.36 \times 10^{-3}$ & 21.72 & $<0.001^{* * *}$ \\
$\bar{L} \times S$ & 1 & $1.06 \times 10^{-3}$ & 6.83 & $0.01^{*}$ \\
Residuals & 152 & $1.55 \times 10^{-4}$ & & \\
\hline
\end{tabular}




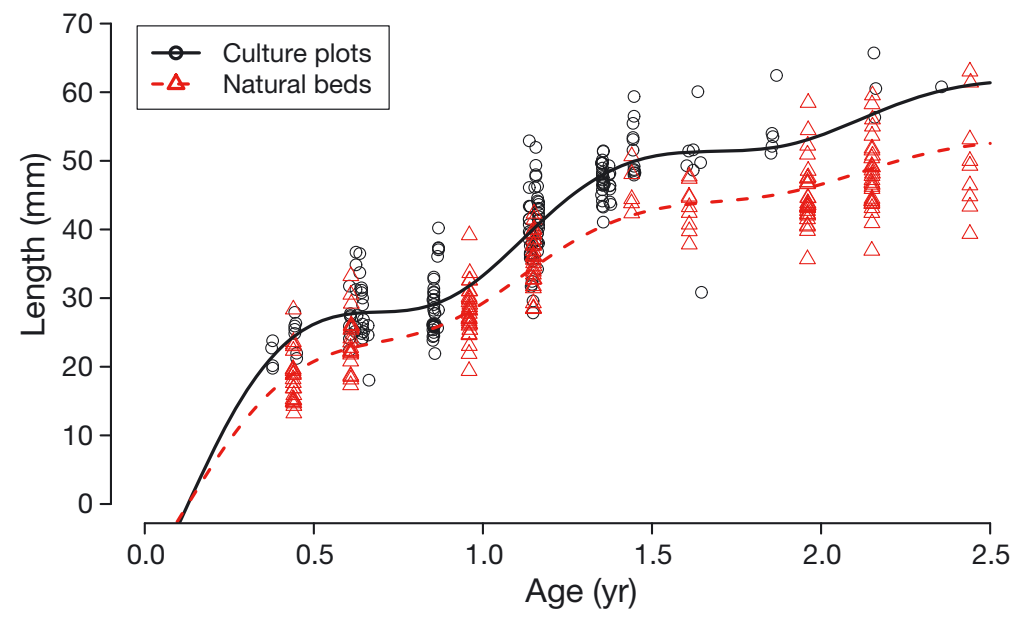

Fig. 4. Mean individual mussel Mytilus edulis shell length from culture plot sampling (2009-2012) and natural mussel bed sampling (2006-2012); data are fitted with a von Bertalanffy growth equation with sinusoidal correction for seasonal oscillations

\section{Biomass simulation}

A biomass simulation with $1 \mathrm{~kg} \mathrm{~m}^{-2}$ of mussel seed on culture plots over time was performed based on VBGF growth parameters found for culture plots (Fig. 7) and with a constant specific loss rate of $2.71 \times$ $10^{-3} \mathrm{~d}^{-1}$ (Fig. 7). Seeding mortality results, on average, in a loss of $28 \%$ of the mussel seed. This causes the initial biomass on culture plots to be lower than on natural beds.

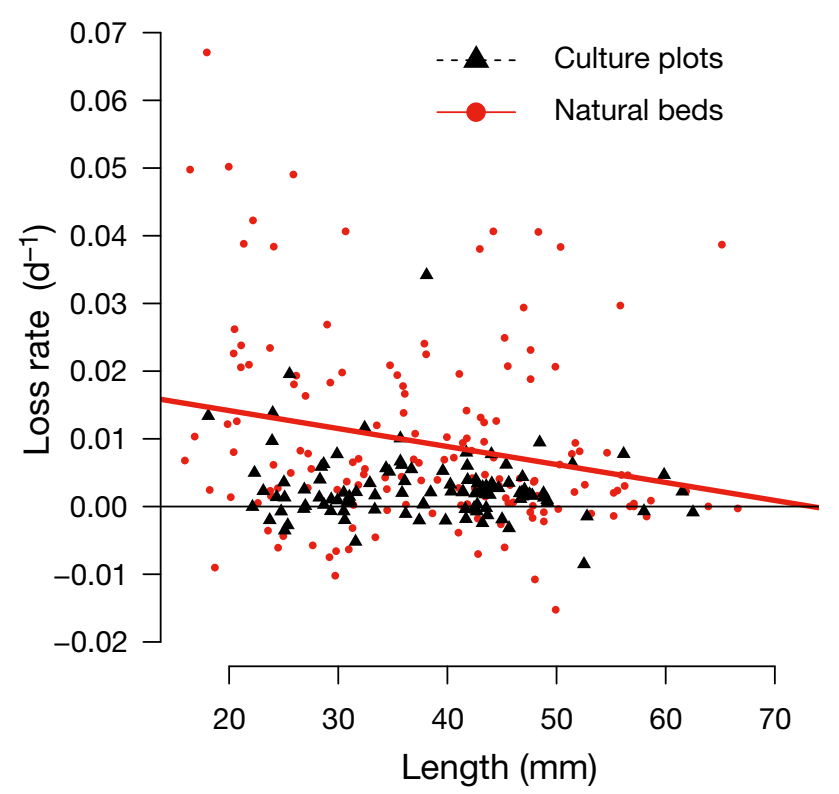

A biomass simulation of $1 \mathrm{~kg} \mathrm{~m}^{-2}$ of mussel seed on a natural mussel bed over time was performed with specific loss rate related to salinity and to shell length and with shell length estimated from the VBGF with parameters for the natural mussel population (Table 1). In Fig. 7, an average biomass simulation is plotted with $r_{\text {natural }}$ estimated by using the average salinity of all sampled plots on natural mussel beds (22.35 ppt). The average biomass on natural mussel beds shows a continuous decrease, whereas an overall increase of biomass is predicted for culture plots; this is also evident from observations (Fig. 3). Both curves intersect about $90 \mathrm{~d}$ after 'seeding' (at a mussel age of $240 \mathrm{~d}$ ), around the end of the year, when mussels are still in their 0 year-class. In the following spring season, the increase in growth rates on culture plots, and especially the lower mortality on these plots compared to natural beds, cause a divergence of the curves. The dotted lines in Fig. 7 represent biomass simulation for natural beds with relatively low salinity (mean $-\mathrm{SD}=$ 20.7 ) and relatively high salinity (mean $+\mathrm{SD}=24.0$ ). At low salinity, mussel biomass development is similar to development on culture plots, but with a decreasing trend. At high salinity, loss processes dominate, and biomass shows a fast exponential

Fig. 5. Relations between specific loss rate and: (a) mean shell length of mussels Mytilus edulis in the corresponding time interval and (b) annual averaged salinity of the sampling location. Both relations are significant for natural mussel beds (red lines), but not for culture plots 

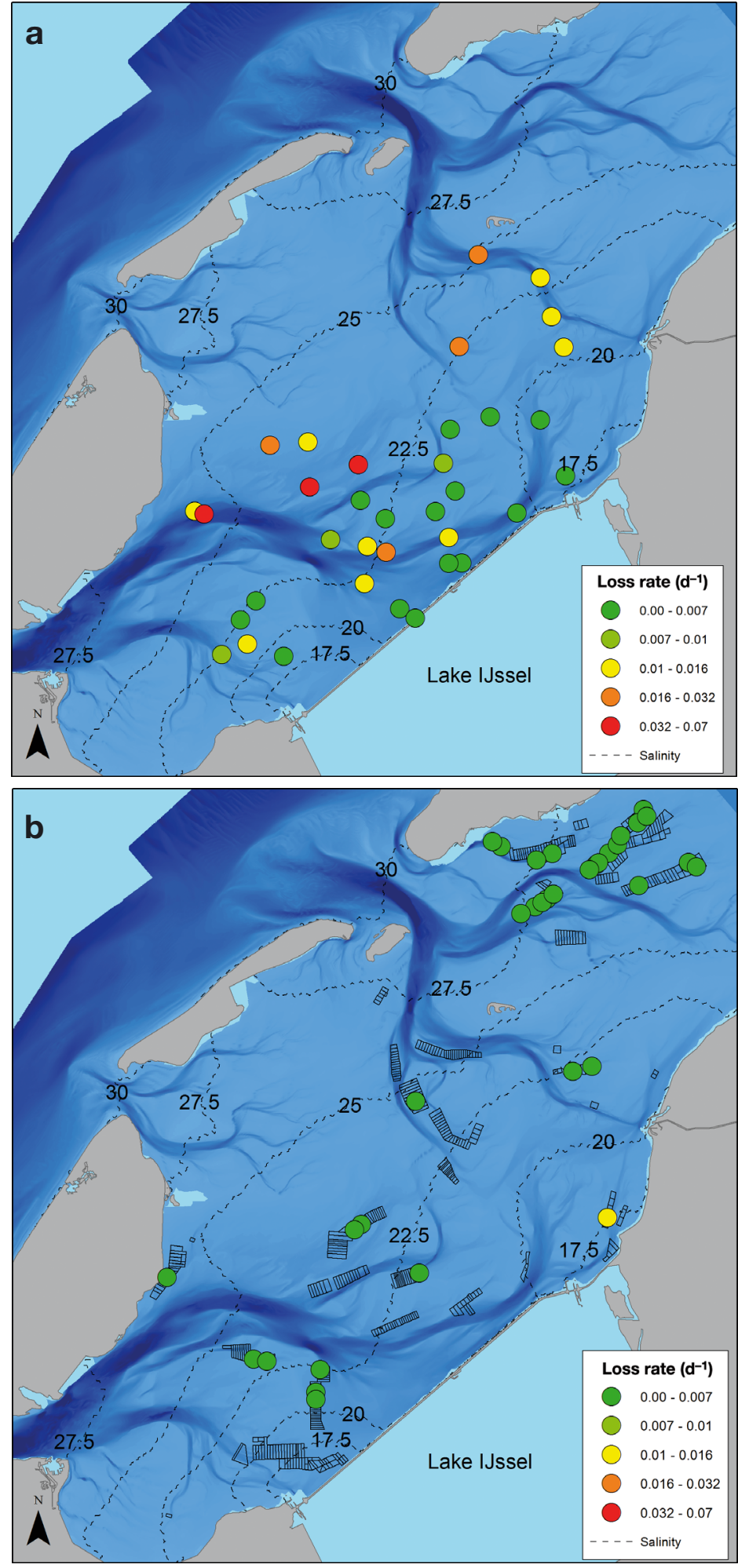

Fig. 6. (a) Spatial patterns in mussel Mytilus edulis loss $\left(\mathrm{d}^{-1}\right)$ per natural mussel bed, showing only sampling stations that were used in the analysis. (b) Average specific loss rates per culture plot (only plots that were used in the analysis). Annual averaged salinity (ppt) is indicated with contour lines decline. These results demonstrate the high sensitivity of mussel biomass development to salinity, caused by the relation between loss rate and salinity.

\section{DISCUSSION}

The sampling program on culture plots was dependent on cooperation with the mussel farmers and followed their activities. On natural mussel beds, monitoring was set up to test fishery effects, and sampling was limited to natural beds in the areas where they were established. Because of these limitations, an experimental approach was not feasible. For example, it would have been interesting to experimentally manipulate mussels in the natural populations (relay seed, control for predation), in order to determine the pure effects of location, salinity and predation control in natural and culture plots. However, this manipulation was not feasible. Nonetheless, the combined sampling programs made it possible to collect a considerable amount of unique data on subtidal mussel populations from natural beds and from culture plots. Both populations were compared, and our results give insight in the survival, growth and impact of cultivation on the dynamics of subtidal mussel populations.

\section{Factors that determine mussel survival on natural mussel beds and culture plots}

There are no indications that the lack of recruitment in the high-salinity zone where the culture plots are located is caused by a lack of larvae in the water or by a lack of natural spatfall. Harvest from mussel seed collectors at various locations shows that spatfall does occur on a yearly basis outside the seed bed establishment areas. Also, the availability of substratum is not a limiting factor (Brinkman et al. 2002). Extensive research mostly on intertidal mussel populations showed that the survival of soft-bottom mussel beds in their early phase depends on the magnitude of physical disturbance and predation pressure (Seed \& Suchanek 1992, Nehls \& Thiel 1993, Hilgerloh et al. 1997, Reusch \& Chapman 1997, Herlyn \& Millat 


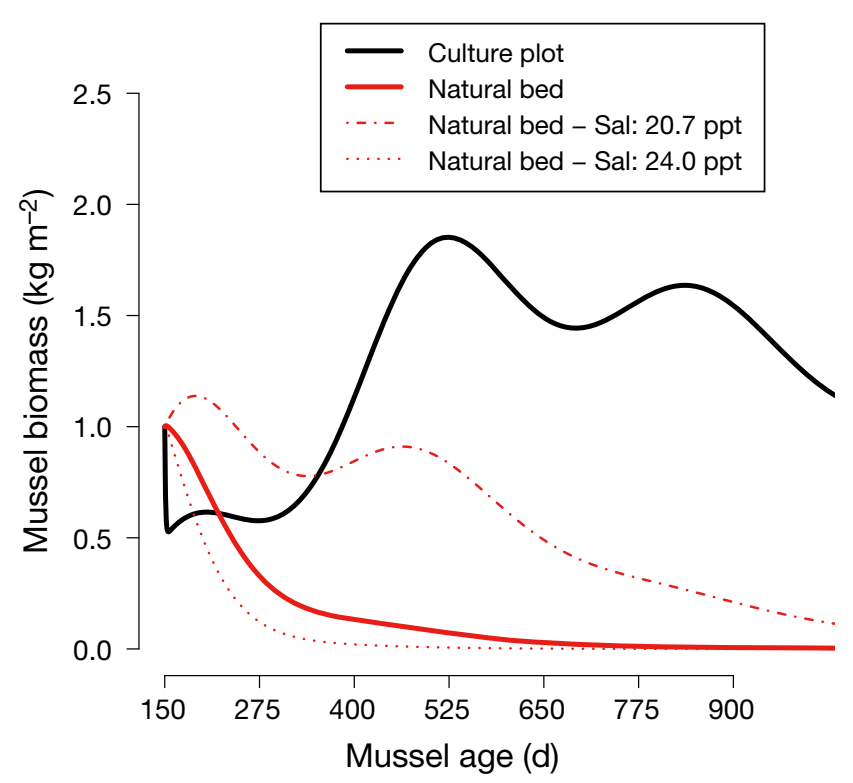

Fig. 7. Simulation of mussel Mytilus edulis biomass, with average loss and growth values calculated from sampling on natural mussel beds and culture plots, including seeding (handling) loss on culture plots; same state variables are used for natural mussel beds and culture plots, dotted lines represent biomass simulations for natural beds with the lower value (mean - SD: $20.7 \mathrm{ppt}$ ) and the upper value (mean + SD: $24.0 \mathrm{ppt}$ ) of the salinity distribution from all natural beds (mean: $22.4 \mathrm{ppt}$ )

2000, Brinkman et al. 2002, Beukema \& Dekker 2007, Van der Heide et al. 2014).

In general, the areas where the culture plots are located are subject to stronger current and wave action than the areas where most of the natural mussel beds are found, as dominant winds come from the SW in the Wadden Sea, and the best performing natural beds are found in areas protected from longfetch waves such as areas at the downstream end of the tidal channel system (Fig. 1). The higher survival rate on the culture plots cannot be attributed to higher physical disturbance on natural mussel beds. Furthermore, in the present study, mussel survival was monitored when seed beds were already established. Mussel seed on these beds have reached a size refuge against predation by fish and shrimps, which are major predators on newly settled mussel spat (Dare 1976, Beukema et al. 1998). Also, the impact of crab predation reduces with mussel size (McGrorty et al. 1993, Murray et al. 2007b). However, predation by the sea star Asterias rubens is a very likely cause for the spatial pattern in survival success in the natural beds (Fig. 6). Notably, a reduction in salinity results in a reduction of sea star feeding activity, and can even diminish the effects of sea stars completely (Agüera et al. 2015). Sea stars can wipe out entire mussel beds in a short period of time (Kristensen \& Lassen 1997, Agüera 2015), but are less tolerant to changes in or low values of salinity than mussels are (Binyon 1976, Shumway 1977, Saranchova \& Flyachinskaya 2001). Monitoring data, published by Ens et al. (2007) and summarized in Fig. 7.2 and 7.3 in Agüera (2015), showed that the frequency of sea stars in a sample $(y)$ increased with salinity $(x)$ according to the power function: $y=0.00016 \mathrm{x}^{1.34}$. Abundance of sea stars in the study area is lower in winter, which is attributed to the lower salinity in winter (Agüera 2015). High temporal fluctuations in salinity occur in regions where water from Lake IJssel enters the Wadden Sea (Duran-Matute et al. 2014). Areas with high temporal fluctuations in salinity are the areas where we find natural mussel beds (Fig. 6). Farther away from these fluctuations, at higher salinities, natural subtidal mussel beds were absent or only survived for a short period (Van Stralen et al. 2013). Hence, better survival of mussels on natural beds in the vicinity of freshwater inputs may be explained by the lower sea star predation pressure in these areas.

Culture plots are located in areas with substantially higher salinities (Figs. 5b \& 6), but are less affected by sea star predation, because sea stars are actively removed by the mussel farmers (Barkhouse et al. 2007). This is also observed in other culture areas. Sea stars are found in large numbers on mussel beds in areas where mussel bottom culture or mussel fishery is practiced: in Wales (Gallagher et al. 2008), the German Wadden Sea (Saier 2001) and Denmark (Kristensen \& Lassen 1997). In these areas, sea star control is common practice.

For large mussels (around $6 \mathrm{~cm}$ shell length), survival is similar in natural subtidal beds and culture plots (Fig. 5a). The positive relation between mussel length and survival in natural mussel populations can be the result of a reduction in sea star predation pressure when mussels are larger (Sommer et al. 1999). Survival of a natural bed would require the bed to pass through the bottleneck of intense predation during several years, which, despite its location in low-salinity zones, has a low probability (see generally higher loss rate of natural beds in Fig. 5, but note that some natural beds do have low loss rates). It can be hypothesized that size-dependence could lead to persistence of the natural beds once a threshold of size-dependent predation is passed. Interestingly, the relation between mussel length and survival was not found on culture plots, which is consistent with the hypothesis that the presence of 
sea stars promotes a length-dependent increase in survival. Similar effects were suggested for the relation between the starfish Pisaster ochraceus and the mussel Mytilus californianus, where the coexistence of predator and prey was only possible when $M$. californianus reached a size refuge against $P$. ochraeus predation (Paine 1976b). The Pisaster-Mytilus relation (in Washington State, USA), is similar to the Asterias-Mytilus relation (NW Europe), to the extent that it involves subtidal populations, with dynamics that are determined by predation and physical disturbance. Furthermore, A. rubens seems to have the same keystone predatory function on $M$. edulis as P. ochraceus has on $M$. californianus (Paine 1976a, Agüera 2015). The mechanism was worked out by Menge \& Sutherland (1987), assuming that environmental stress has a higher impact on mobile consumers than on sessile organisms. Their theory predicts that in high-stress environments (e.g. at low salinities) consumers and sessile organisms are absent or not active. In more moderate environments, sessile organisms are less affected by environmental stress than consumers, resulting in the establishment of sessile populations. In benign environments, sessile organisms can only thrive when they pass through an intense predation bottleneck. This theory is consistent with the Asterias-Mytilus relation in the Wadden Sea, where mussel populations can most likely only persist in benign environments if they pass the predation bottleneck through mediation of the mussel farmer. Furthermore, Fig. 6 shows that viable mussel populations were also absent in the very low-salinity regions (<17.5 ppt). Yet, the outcome of the long-term monitoring on the plots closed to fishery is that all mussels disappeared in a period of $7 \mathrm{yr}$ (Van Stralen et al. 2015). Therefore, the question remains to what extent longer-term survival of a natural mussel population in the subtidal zone of the western Wadden Sea is probable. In the period when natural beds were monitored, large-scale recruitment regularly resulted in new mussel seed beds (Van Stralen et al. 2015). When frequent recruitment on older mussel beds does not take place, the longevity of a cohort is limited, in our study to about $7 \mathrm{yr}$. Hence, the long-term survival of subtidal natural mussel populations appears to be recruitment driven.

On culture plots, other loss factors may be more dominant than sea star predation, such as loss associated with relaying or density-dependent losses (Gascoigne et al. 2005, Capelle et al. 2016). The loss rate of mussels surviving the initial seeding is uncorrelated with length or salinity, and is notably less variable than loss rate in natural beds (Fig. 5). This constancy may be the result of measures by mussel farmers (e.g. adjusting seeding density, mud removal), and reflect the quality-based selection of the culture plots.

\section{Effects of relay on mussel growth}

Fig. 4 and underlying data indicate that growth rates of natural mussels, even when they persist for longer periods, are lower than on culture plots. This is ascribed to lower salinity and a higher turbidity near Lake IJssel (Piersma \& Camphuysen 2001, De Jonge \& De Jong 2002, Drent \& Dekker 2013, DuranMatute et al. 2014), which can both individually or jointly reduce growth. Mussels remain smaller and display low growth rates in areas where salinity is low or strongly fluctuating (Bøhle 1972, AlmadaVillela 1984, Gruffydd et al. 1984, Westerbom et al. 2002, Riisgård et al. 2012, 2013). However, Maar et al. (2015) observed significant reductions in growth only at salinity values $<15 \mathrm{ppt}$. This value is well below the average values found at the mussel bed locations (Fig. 2); we therefore expect that differences in growth are more related to spatial differences in food quality. Spatial variability in chlorophyll $a$ in the Marsdiep basin is not very well described, but appears to be limited, based on long-term monitoring data of Rijkswaterstaat. It is expected that variability in food quality mainly depends on the spatial variability in SPM, as the ratio of chlorophyll a to SPM is a well-documented measure of food quality. Hawkins et al. (1996) found that mussels are able to cope with high silt concentrations and can adapt to short-term changes in silt-related food quality, by altering their feeding behaviour (Bayne 1998, Hawkins et al. 1998). This adaptability was demonstrated for a range of SPM levels (10-90 $\mathrm{mg} \mathrm{l}^{-1}$ ) that is very similar to the natural range reported for the Marsdiep area in the Wadden Sea (De Jonge et al. 1996). Although mussel populations can persist under these conditions, inorganic matter reduces food quality and thus mussel growth rates in shellfish production (Newell et al. 1998, Scholten \& Smaal 1999). Furthermore, high SPM levels can reduce primary production in estuaries by limiting light penetration through the water column (Wilson 2002).

\section{Impact of cultivation}

Traditional culture relies on the relay of mussel seed from natural mussel beds to culture plots. Our 
results point out that culture potentially leads to an increase in mussel biomass within the Wadden Sea. Mussels from culture plots are harvested after they reach market size, or even before when transplanted to culture plots outside the Wadden Sea, notably the Eastern Scheldt, resulting in a short turnover time of mussel biomass. Nonetheless, it was estimated over the period 2004 to 2012 that mussel culture for this period resulted on average in 1.27 times more mussels than there would be in the absence of culture, in a study based on a budget calculation approach using mussel stock estimations, seed fishery statistics, harvest and transplantation data (Wijsman et al. 2014). An increase in mussel biomass may reduce the carrying capacity of the system for other shellfish, such as cockles, an important food source for birds. Model calculations by Kamermans et al. (2014) predicted that when mussel numbers increase because of an increase in mussel seed collectors, some negative effects on shellfish biomass can be expected for confined areas in the western Wadden Sea, although due to spatial differences in the distribution of shellfish stocks, such effects are less probable for areas where culture plots are located.

Bivalve aquaculture provides ecosystem goods and services (Smaal et al. 2001a, Newell 2004, Saurel et al. 2014, Ferreira \& Bricker 2016), including a reduction in eutrophication, increase in water column visibility and provision of habitat and food for higher trophic levels (Suchanek 1992, Inglis \& Gust 2003, Newell \& Koch 2004, Rönnbäck et al. 2007, Diana 2009). A healthy mussel population, by means of extensive mussel culture, supports more subtidal biodiversity, and provides a food source for birds (Buschbaum et al. 2009, Ysebaert et al. 2009). In fact, species richness on subtidal culture plots in the western Wadden Sea was not lower than on natural mussel beds (Drent \& Dekker 2013), but those authors noted that species richness generally increased with salinity, so that the effect could partly be caused by the higher salinity at the location of the culture plots, compared to the natural beds. Furthermore, cultured mussels are a suitable food source for birds not only because of the size of the stock, but also because better growth conditions on culture plots will result in mussels with more meat (Capelle et al. 2016). Consistently, bird counts confirm that culture plots are vital foraging grounds for eider ducks (Smaal et al. 2010, Cervencl et al. 2015). Eider ducks prefer medium and large sized mussels above other food sources and are therefore also an important predator on culture plots; annual mussel consumption from culture plots between 2008 and 2011 was estimated to range between 4.5 and 8.2 million $\mathrm{kg}$ fresh weight of mussels (Cervencl et al. 2015).

\section{CONCLUSIONS}

Survival of mussels on natural beds in the Wadden Sea was lower than on culture plots except for larger mussel sizes, which had probably reached a size refuge for predation. Survival of natural mussel populations decreased with salinity. Natural mussel populations in this region are limited to areas with low and strongly fluctuating salinities. This pattern is consistent with the explanation that the natural subtidal mussel population is controlled by sea star predation. Sea stars are keystone predators on subtidal mussels in the Wadden Sea, but have a lower tolerance for low or strongly fluctuating salinities than mussels. The vast majority of culture plots are situated in areas with a relative high salinity and food quality, beneficial to both sea stars and mussels, which explains why natural mussel beds seldom establish in that area. However, the cultured mussel population can pass through the predation bottleneck by mediation of the mussel farmers who actively remove sea stars from the culture plots. On culture plots, mussel growth was higher and growing conditions were more favourable than on natural beds where mussels must cope with lower food quality. Mussel culture affects the population dynamics of the subtidal mussels in the system by relaying mussels from natural beds to culture plots. This activity results in a higher mussel biomass production on culture plots than on natural beds; it also enhances the total subtidal mussel stock within the system, favouring ecosystem services such as the provision of subtidal biodiversity and a high-quality food source for birds.

Acknowledgements. Culture plot sampling was undertaken with MS 'Stormvogel' and MS 'Phoca' with help from fishery officers from the Ministry of Economic Affairs: Nico Laros, Theo van Malsen, Eelke Sybren Dijkstra and Arjen Dijkstra. We are grateful for the cooperation with the mussel sector in this study. Special thanks in this regard in no particular order to: Jan and Joachim Schot, Marinus Padmos, Cees Otte, Adrian, Jos and Johnny Steketee, Jos van Damme and Albert Nieuwenhuize. Sampling of natural mussel beds was undertaken with MS 'YE-42'. We acknowledge Johan Jol (IMARES) for help with sample collection and processing. This work was part of the PRODUS project that was funded by the PO Mossel and the Ministry of Economic Affairs. We are grateful to 3 anonymous referees for their helpful and valuable comments. 


\section{LITERATURE CITED}

Agüera A (2015) The role of starfish (Asterias rubens L.) predation in blue mussel (Mytilus edulis) seedbed stability. $\mathrm{PhD}$ dissertation, Wageningen University

Agüera A, Schellekens T, Jansen JM, Smaal AC (2015) Effects of osmotic stress on predation behaviour of Asterias rubens L. J Sea Res 99:9-16

Almada-Villela PC (1984) The effects of reduced salinity on the shell growth of small Mytilus edulis. J Mar Biol Assoc UK 64:171-182

Alterra (2005) Passende beoordeling sublitorale mosselzaadvisserij in de westelijke Waddenzee [Assessment of subtidal mussel fisheries in the western Wadden Sea]. Alterra, Texel, and RIVO, Yerseke

Asmus H, Asmus RM (2002) ECSA workshop: community ecology of soft bottom mussel beds. Helgol Mar Res 56: $1-2$

Barkhouse CL, Niles M, Davidson LA (2007) A literature review of sea star control methods for bottom and off bottom shellfish cultures. Canadian Industry Report of Fisheries and Aquatic Sciences 279. Fisheries and Oceans Canada, Ottawa

Bayne BL (1998) The physiology of suspension feeding by bivalve molluscs: an introduction to the Plymouth 'TROPHEE' workshop. J Exp Mar Biol Ecol 219:1-19

Beadman HA, Caldow RWG, Kaiser MJ, Willows RI (2003) How to toughen up your mussels: using mussel shell morphological plasticity to reduce predation losses. Mar Biol 142:487-494

Beukema JJ, Dekker R (2007) Variability in annual recruitment success as a determinant of long-term and largescale variation in annual production of intertidal Wadden Sea mussels (Mytilus edulis). Helgol Mar Res 61:71-86

Beukema JJ, Honkoop PJC, Dekker R (1998) Recruitment in Macoma balthica after mild and cold winters and its possible control by egg production and shrimp predation. Hydrobiologia 375/376:23-34

Binyon J (1976) The effects of reduced salinity upon the starfish Asterias rubens L. together with a special consideration of the integument and its permeability to water. Thalassia Jugosl 12:11-20

Bøhle B (1972) Effects of adaptation to reduced salinity on filtration activity and growth of mussels (Mytilus edulis L.). J Exp Mar Biol Ecol 10:41-47

Borthagaray AI, Carranza A (2007) Mussels as ecosystem engineers: their contribution to species richness in a rocky littoral community. Acta Oecol 31:243-250

Brinkman A, Dankers N, Van Stralen M (2002) An analysis of mussel bed habitats in the Dutch Wadden Sea. Helgol Mar Res 56:59-75

Buschbaum C, Dittmann S, Hong JS, Hwang IS and others (2009) Mytilid mussels: global habitat engineers in coastal sediments. Helgol Mar Res 63:47-58

Büttger H, Asmus H, Asmus R, Buschbaum C, Dittmann S, Nehls G (2008) Community dynamics of intertidal softbottom mussel beds over two decades. Helgol Mar Res 62:23-36

Capelle JJ, Wijsman JW, van Stralen MR, Herman PM, Smaal AC (2016) Effect of seeding density on biomass production in mussel bottom culture. J Sea Res 110:8-15

Cervencl A, Troost K, Dijkman E, de Jong M, Smit C, Leopold M, Ens B (2015) Distribution of wintering common eider Somateria mollissima in the Dutch Wadden Sea in relation to available food stocks. Mar Biol 162:153-168
Commito JA, Dankers NMJA (2001) Dynamics of spatial and temporal complexity in European and North American soft-bottom mussel beds. Ecol Stud 151:39-59

* Commito JA, Commito AE, Platt RV, Grupe BM and others (2014) Recruitment facilitation and spatial pattern formation in soft-bottom mussel beds. Ecosphere 5:art160

* Dankers N, Zuidema DR (1995) The role of the mussel (Mytilus edulis L.) and mussel culture in the Dutch Wadden Sea. Estuaries 18:71-80

Dare PJ (1976) Settlement, growth and production of the mussel Mytilus edulis L. in Morecambe Bay, England. Fish Invest II 28:1-25

Davenport JC, Black K, Burnell G, Cross T and others (2009) Aquaculture: the ecological issues. John Wiley \& Sons, Oxford

* De Jonge VN, De Jong DJ (2002) 'Global change' impact of inter-annual variation in water discharge as a driving factor to dredging and spoil disposal in the River Rhine system and of turbidity in the Wadden Sea. Estuar Coast Shelf Sci 55:969-991

*De Jonge VN, Bakker JF, Van Stralen M (1996) Recent changes in the contributions of river Rhine and North Sea to the eutrophication of the western Dutch Wadden Sea. Neth J Aquat Ecol 30:27-39

*Diana JS (2009) Aquaculture production and biodiversity conservation. Bioscience 59:27-38

* Dolmer P, Sand Kristensen P, Hoffmann E (1999) Dredging of blue mussels (Mytilus edulis L.) in a Danish sound: stock sizes and fishery-effects on mussel population dynamic. Fish Res 40:73-80

Dolmer P, Kristensen T, Christiansen M, Petersen M, Kristensen PS, Hoffmann E (2001) Short-term impact of blue mussel dredging (Mytilus edulis L.) on a benthic community. Hydrobiologia 465:115-127

* Dolmer P, Christensen HT, Hansen BW, Vismann B (2012) Area-intensive bottom culture of blue mussels Mytilus edulis in a micro-tidal estuary. Aquacult Environ Interact 3:81-91

Drent J, Dekker R (2013) How different are subtidal Mytilus edulis L. communities of natural mussel beds and mussel culture plots in the western Dutch Wadden Sea? NIOZreport 2013-6. Royal Netherlands Institute for Sea Research (NIOZ), Texel

* Duran-Matute M, Gerkema T, de Boer GJ, Nauw JJ, Gräwe U (2014) Residual circulation and freshwater transport in the Dutch Wadden Sea: a numerical modelling study. Ocean Sci 10:611-632

Ens BJ, Craeymeersch JAM, Fey FE, Smaal AC and others (2007) Sublitorale natuurwaarden in de Waddenzee [Natural values of the subtidal Wadden Sea]. C077/07. IMARES, Wageningen

Ferreira J, Bricker S (2016) Goods and services of extensive aquaculture: shellfish culture and nutrient trading. Aquacult Int 24:803-825

Folmer EO, Drent J, Troost K, Büttger H and others (2014) Large-scale spatial dynamics of intertidal mussel ( $M y-$ tilus edulis L.) bed coverage in the German and Dutch Wadden Sea. Ecosystems 17:550-566

Frandsen RP, Eigaard OR, Poulsen LK, Tørring D, Stage B, Lisbjerg D, Dolmer P (2015) Reducing the impact of blue mussel (Mytilus edulis) dredging on the ecosystem in shallow water soft bottom areas. Aquat Conserv 25: 162-173

Gallagher T, Richardson CA, Seed R, Jones T (2008) The seasonal movement and abundance of the starfish, Aste- 
rias rubens in relation to mussel farming practice: a case study from the Menai Strait, UK. J Shellfish Res 27: 1209-1215

Gascoigne JC, Beadman HA, Saurel C, Kaiser MJ (2005) Density dependence, spatial scale and patterning in sessile biota. Oecologia 145:371-381

Gosling E (2003) Bivalve molluscs. Biology, ecology and culture. Blackwell Publishing, Oxford

* Gruffydd LD, Huxley R, Crisp DJ (1984) The reduction in growth of Mytilus edulis in fluctuating salinity regimes measured using laser diffraction patterns and the exaggeration of this effect by using tap water as the diluting medium. J Mar Biol Assoc UK 64:401-409

Gutiérrez JL, Jones CG, Byers JE, Arkema KK and others (2011) Physical ecosystem engineers and the functioning of estuaries and coasts. In: Wolanski E, McLusky DS (eds) Treatise on estuarine and coastal science, Vol 7. Academic Press, Waltham, p 53-81

Hawkins AJS, Smith RFM, Bayne BL, Héral M (1996) Novel observations underlying the fast growth of suspensionfeeding shellfish in turbid environments: Mytilus edulis. Mar Ecol Prog Ser 131:179-190

* Hawkins AJS, Bayne BL, Bougrier S, Héral M and others (1998) Some general relationships in comparing the feeding physiology of suspension-feeding bivalve molluscs. J Exp Mar Biol Ecol 219:87-103

* Herlyn M, Millat G (2000) Decline of the intertidal blue mussel (Mytilus edulis) stock at the coast of Lower Saxony (Wadden Sea) and influence of mussel fishery on the development of young mussel beds. Hydrobiologia 426: 203-210

Hilgerloh G, Herlyn M, Michaelis H (1997) The influence of predation by herring gulls Larus argentatus and oystercatchers Haematopus ostralegus on a newly established mussel Mytilus edulis bed in autumn and winter. Helgol Mar Res 51:173-189

Inglis GJ, Gust N (2003) Potential indirect effects of shellfish culture on the reproductive success of benthic predators. J Appl Ecol 40:1077-1089

Kaiser M, Laing I, Utting S, Burnell G (1998) Environmental impacts of bivalve mariculture. J Shellfish Res 17:59-66

Kaiser MJ, Clarke KR, Hinz H, Austen MCV, Somerfield PJ, Karakassis I (2006) Global analysis of response and recovery of benthic biota to fishing. Mar Ecol Prog Ser 311:1-14

Kamermans P, Smit CJ, Wijsman JWM, Smaal AC (2014) Meerjarige effect- en productiemetingen aan MZI's in de Westelijke Waddenzee, Oosterschelde en Voordelta: samenvattend eindrapport [Long term measurements on effects and production of SMCs in the western Wadden Sea]. IMARES, Wageningen UR, Yerseke

Kimura DK (1980) Likelihood methods for the von Bertalanffy growth curve. Fish Bull 77:765-776

Kristensen PS, Lassen H (1997) The production of relaid blue mussels (Mytilus edulis L.) in a Danish fjord. ICES J Mar Sci 54:854-865

Laursen K, Asferg KS, Frikke J, Sunde P (2009) Mussel fishery affects diet and reduces body condition of eiders Somateria mollissima in the Wadden Sea. J Sea Res 62: 22-30

Lenihan HS, Micheli F (2001) Soft-sediment communities. In: Bertness M, Hay ME, Gaines SD (eds) Marine community ecology. Sinauer Associates, Sunderland, MA, p 253-287

Lotze HK, Reise K, Worm B, van Beusekom J and others
(2005) Human transformations of the Wadden Sea ecosystem through time: a synthesis. Helgol Mar Res 59:84-95

* Maar M, Saurel C, Landes A, Dolmer P, Petersen JK (2015) Growth potential of blue mussels ( $M$. edulis) exposed to different salinities evaluated by a Dynamic Energy Budget model. J Mar Syst 148:48-55

*McGrorty S, Clarke RT, Reading CJ, Goss-Custard JD (1990) Population dynamics of the mussel Mytilus edulis: density changes and regulation of the population in the Exe estuary, Devon. Mar Ecol Prog Ser 67:157-169

McGrorty S, Goss-Custard JD, Clarke RT (1993) Mussel Mytilus edulis (Mytilacea) dynamics in relation to environmental gradients and intraspecific interactions. Neth J Aquat Ecol 27:163-171

*Menge BA, Sutherland JP (1987) Community regulation: variation in disturbance, competition, and predation in relation to environmental stress and recruitment. Am Nat 130:730-757

Murray LG, Newell CR, Seed R (2007a) Changes in the biodiversity of mussel assemblages induced by two methods of cultivation. J Shellfish Res 26:153-162

* Murray LG, Seed R, Jones T (2007b) Predicting the impacts of Carcinus maenas predation on cultivated Mytilus edulis beds. J Shellfish Res 26:1089-1098

Nehls G, Thiel M (1993) Large-scale distribution patterns of the mussel Mytilus edulis in the Wadden Sea of Schleswig-Holstein: Do storms structure the ecosystem? Neth J Sea Res 31:181-187

Nehls G, Witte S, Büttger H, Dankers N and others (2009) Beds of blue mussels and Pacific oysters. Thematic report no. 11. In: Marencic H, de Vlas J (eds) Quality status report 2009. Wadden Sea ecosystem no. 25. Common Wadden Sea Secretariat, Trilateral Monitoring and Assessment Group, Wilhelmshaven, p 1-29

Newell RIE (2004) Ecosystem influences of natural and cultivated populations of suspension-feeding bivalve molluscs: a review. J Shellfish Res 23:51-61

*Newell RI, Koch EW (2004) Modeling seagrass density and distribution in response to changes in turbidity stemming from bivalve filtration and seagrass sediment stabilization. Estuaries 27:793-806

Newell CR, Campbell DE, Gallagher SM (1998) Development of the mussel aquaculture lease site model MUSMOD $\odot:$ a field program to calibrate model formulations. J Exp Mar Biol Ecol 219:143-169

Ogle DH (2015a) Introductory fisheries analyses with R. CRC Press, Boca Raton, FL

Ogle DH (2015b) FSA: fisheries stock analysis. R package version 0.8.4. http://CRAN.R-project. org/package=FSA

Paine R (1976a) Biological observations on a subtidal Mytilus californianus bed. Veliger 19:125-130

Paine R (1976b) Size limited predation: an observational and experimental approach with the Mytilus Pisaster interaction. Ecology 57:858-873

Piersma T, Camphuysen CJ (2001) What can peak mortality of eiders tell us about the state of the Dutch Wadden Sea Ecosystem. Wadden Sea Newsl 2001:42-45

Pinheiro J, Bates D, DebRoy S, Sarkar D, R Core Team (2014) nlme: Linear and nonlinear mixed effects models. $\mathrm{R}$ package version 3.1-117. http://CRAN.R-project.org/ package $=$ nlme

R Core Team (2016) R: a language and environment for statistical computing. R Foundation for Statistical Computing, Vienna

Reusch TBH, Chapman ARO (1997) Persistence and space 
occupancy by subtidal blue mussel patches. Ecol Monogr 67:65-87

Ridderinkhof H, Zimmerman JTF, Philippart ME (1990) Tidal exchange between the North Sea and Dutch Wadden Sea and mixing time scales of the tidal basins. Neth J Sea Res 25:331-350

Riisgård HU, Bøttiger L, Pleissner D (2012) Effect of salinity on growth of mussels, Mytilus edulis, with special reference to Great Belt (Denmark). Open J Mar Sci 2:167-176

Riisgård HU, Lüskow F, Pleissner D, Lundgreen $\mathrm{K}$, López MÁP (2013) Effect of salinity on filtration rates of mussels Mytilus edulis with special emphasis on dwarfed mussels from the low-saline Central Baltic Sea. Helgol Mar Res 67:591-598

Rönnbäck P, Kautsky N, Pihl L, Troell M, Söderqvist T, Wennhage $H$ (2007) Ecosystem goods and services from Swedish coastal habitats: identification, valuation, and implications of ecosystem shifts. Ambio 36:534-544

Saier B (2001) Direct and indirect effects of seastars Asterias rubens on mussel beds (Mytilus edulis) in the Wadden Sea. J Sea Res 46:29-42

Saranchova OL, Flyachinskaya LP (2001) The influence of salinity on early ontogeny of the mussel Mytilus edulis and the starfish Asterias rubens from the White Sea. Russ J Mar Biol 27:87-94

Saurel C, Ferreira JG, Cheney D, Suhrbier A, Dewey B, Davis J, Cordell J (2014) Ecosystem goods and services from Manila clam culture in Puget Sound: a modelling analysis. Aquacult Environ Interact 5:255-270

Scholten H, Smaal AC (1999) The ecophysiological response of mussels (Mytilus edulis) in mesocosms to a range of inorganic nutrient loads: simulations with the model EMMY. Aquat Ecol 33:83-100

Seed R, Suchanek TH (1992) Population and community ecology of Mytilus. In: Gosling E (ed) The mussel Mytilus: ecology, physiology, genetics and culture. Elsevier, Amsterdam, p 87-170

Shumway SE (1977) The effects of fluctuating salinities on four species of asteroid echinoderms. Comp Biochem Physiol A Mol Integr Physiol 58:177-179

Smaal A, Van Stralen M, Schuiling E (2001a) The interaction between shellfish culture and ecosystem processes. Can J Fish Aquat Sci 58:991-1002

Smaal AC, Craemeersch J, Kamermans P, van Stralen MR (2001b) Is food shortage the cause of eider duck mortality? Shellfish and crab abundance in the Dutch Wadden Sea 1994 - 1999. Wadden Sea Newsl 1:35-38

Smaal AC, Wijsman JWM, Van Stralen MR (2010) Mussel culture and subtidal mussel stock management in the western Wadden Sea: Are exploitation and conservation compatible? Wadden Sea Ecosyst 26:145-150

Smit CJ, Dankers N, Ens BJ, Meijboom A (1998) Birds, mussels, cockles and shellfish fishery in the Dutch Wadden

Editorial responsibility: Gianluca Sará,

Palermo, Italy
Sea: how to deal with low food stocks for eiders and oystercatchers? Senckenb Marit 29:141-153

Smith J, Shackley SE (2004) Effects of a commercial mussel Mytilus edulis lay on a sublittoral, soft sediment benthic community. Mar Ecol Prog Ser 282:185-191

Somers IF (1988) On a seasonally oscillating growth function. Fishbyte 6:8-11

* Sommer U, Meusel B, Stielau C (1999) An experimental analysis of the importance of body-size in the seastarmussel predator-prey relationship. Acta Oecol 20:81-86

K Stillman RA, Goss-Custard JD, West AD, Dit Durell SEAL and others (2001) Predicting shorebird mortality and population size under different regimes of shellfishery management. J Appl Ecol 38:857-868

Suchanek T (1992) Extreme biodiversity in the marine environment: mussel bed communities of Mytilus californianus. Northwest Environ J 8:150-152

van Aken HM (2008) Variability of the salinity in the western Wadden Sea on tidal to centennial time scales. J Sea Res 59:121-132

Van de Kam J, De Goeij P, Moore SJ, Ens B, Piersma T, Zwarts L (2004) Shorebirds: an illustrated behavioural ecology. KNNV Publishers, Utrecht

*Van der Heide T, Tielens E, van der Zee EM, Weerman EJ and others (2014) Predation and habitat modification synergistically interact to control bivalve recruitment on intertidal mudflats. Biol Conserv 172:163-169

Van Stralen MR, Craeymeersch J, Drent J, Glorius S, Jansen JM, Smaal AC (2013) Het mosselbestand op de PRODUS vakken en de effecten van de visserij daarop [Effects of fishery on mussel stock on experimental PRODUS plots]. MarinX, Scharendijke

Van Stralen MR, Van den Ende D, Troost K (2015) Inventarisatie van het sublitorale wilde mosselbestand in de westelijke Waddenzee in het voorjaar van 2015 [Inventorization of natural subtidal mussel stock in the western Wadden Sea in the Spring of 2015]. MarinX, Scharendijke

Westerbom M, Kilpi M, Mustonen O (2002) Blue mussels, Mytilus edulis, at the edge of the range: population structure, growth and biomass along a salinity gradient in the north-eastern Baltic Sea. Mar Biol 140:991-999

Wijsman JWM, Schellekens T, Van Stralen M, Capelle JJ, Smaal AC (2014) Rendement van mosselkweek in de westelijke Waddenzee [Efficiency of mussel culture in the western Wadden Sea]. IMARES, Wageningen UR, Yerseke

Wilson JG (2002) Productivity, fisheries and aquaculture in temperate estuaries. Estuar Coast Shelf Sci 55:953-967

* Ysebaert T, Hart M, Herman PMJ (2009) Impacts of bottom and suspended cultures of mussels Mytilus spp. on the surrounding sedimentary environment and macrobenthic biodiversity. Helgol Mar Res 63:59-74

Submitted: July 26, 2016; Accepted: February 13, 2017

Proofs received from author(s): March 18, 2017 